\title{
Phytochemical Analysis of Flower, Leaf and Root of Achyranthes Aspera from Durg District of Chhattisgarh- A Comparative Study
}

\author{
Nisreen Husain ${ }^{1}$, Anil Kumar ${ }^{2}$ \\ ${ }^{1}$ Department of Zoology, Govt. Dr. W.W. Patankar Girls' PG. College, Durg (C.G.) 491001, India \\ ${ }^{2}$ Department of Zoology, Govt. V.Y.T.P.G. Autonomous College, Durg (C.G.) 491001, India
}

\begin{abstract}
A large number of Indian medicinal plants have been the important components of traditional medicinal system, and also in modern pharmaceuticals. Their biologically active functions and medicinal value is due to the presence of a wide range of chemical compounds in different parts of the plants. Most of such compounds act as natural antioxidants, and help in reducing the incidences of diseases and early ageing. In the present study, all the seven groups of the important phytocompounds, viz., Cardiac glycosides, Steroids, Alkaloids, Flavonoids, Terpenoids, Tannins and Saponins, were screened from the different parts of the well known medicinal herb, Achyranthes aspera. Their presence was revealed through in vitro phytochemical screening of methanolic and chloroformic extracts of flower, leaf and root of Achyranthes aspera. The analysis for the same was carried out by qualitative tests for which the standard protocol was followed. Methanolic flower and root extracts were found as the good sources of phytoactive constituents. Both methanolic and chloroformic extracts of flowers, leaf and root showed the distinct presence of Steroids. Flower and root parts ascertained the presence of Terpenoids. Methanolic extracts of three of the plant parts were found to consist of good stores of phytochemicals as compared to the chloroformic extracts.
\end{abstract}

Keywords: Phytochemical compounds, Secondary metabolites, Steroids, Flavonoids, Cardiac glycosides, Tannins, Saponins, Alkaloids and Terpenoids

\section{Introduction}

The diversified species of medicinal plants have been the basis of traditional and modern medicinal systems, and herbal drugs as well. Their medicinal and pharmacological values attribute to their efficacy in treatment of many dreadful diseases and early ageing. This has increased the rapid research and exploration of more of such plants with therapeutic potentials and herbal formulations [1]. The medicinal plants are known as the store houses of special organic compounds synthesized by the plants themselves. These phytochemical compounds are responsible for the beneficial and medicinal properties of the plants [2]. The remarkable bioactivities and antioxidant properties of the medicinal plants owe to the combinations of secondary products and phytochemicals present in different parts of the plants. Most of such compounds function as natural antioxidants with the ability to prevent the oxidative damage caused by free radicals, thereby controlling the risk of infectious diseases [3]. Hence, the medicinal plants with rich phytochemical constituents are used for potent and effective drugs [4,5]. The significant phytoactive compounds screened in the present study are Cardiac glycosides, Steroids, Alkaloids, Flavonoids, Terpenoids, Tannins and Saponins.

The plant selected for the present work, was Achyranthes aspera, an indigenous medicinal herb, wildly growing throughout India, especially Chhattisgarh. The herb is particularly known for its anti-parasitic, spemicidal, antiinflammatory, wound healing and antioxidant properties $[6,7,8]$. The whole plant of Achyranthes aspera is traditionally used in the treatment of skin problems, asthama, rheumatism and gastric disorders [9,10]. The aqueous paste of flowering spikes, the paste of fresh leaves and the root infusion have been commonly found effective against snake bites, strained back and wasp bites, and ophthalmic and bowel complaints respectively [10,11,12]. The varied range of bioactivities and medicinal properties of the extracts of Achyranthes aspera is due to the presence of phytochemical constituents. The focus of the present study is the comparative analysis of important phytochemicals screened in the flower, leaf and root extracts of Achyranthes aspera prepared in methanol and chloroform separately.

\section{Materials and Methods}

\section{Collection and Preparation of Extract}

The medicinal herb of Achyranthes aspera of healthy growth were collected from the open grounds and fields of some areas of Durg, Chhattisgarh. The different plant-parts, i.e., flowers, leaves and roots were separated from the plants, washed and shade dried for a few days. The dried plant-parts were grinded into coarse powder separately. The extract of each plant-part (flower, leaf and root) was prepared using different solvents, Methanol (59\%) and Chloroform separately by Soxhlet Extraction apparatus.

\section{Methods for Phytochemical screening tests}

Test for Cardiac glycosides

$0.5 \mathrm{ml}$ of each of the extract was dissolved in $2 \mathrm{ml}$ Glacial acetic acid alongwith $1 \%$ Ferric Chloride $\left(\mathrm{FeCl}_{3}\right)$. This solution was underlayered with $1 \mathrm{ml}$ of Sulphuric acid $\left(\mathrm{H}_{2} \mathrm{SO}_{4}\right)$. The presence of Cardiac glycosides was indicated by the formation of a brown ring at the interface. 


\section{International Journal of Science and Research (IJSR) \\ ISSN (Online): 2319-7064}

Index Copernicus Value (2013): 6.14 | Impact Factor (2014): 5.611

Test for Steroids

Each of the extract $(0.5 \mathrm{ml})$ was dissolved in $3 \mathrm{ml}$ of Chloroform $\left(\mathrm{CHCl}_{3}\right)$. This was filtered, and a lower layer was observed on adding a few drops of conc. Sulphuric acid $\left(\mathrm{H}_{2} \mathrm{SO}_{4}\right)$ to the filtrate. Appearance of a ring of reddish brown color indicated the presence of Steroids.

\section{Test for Flavonoids}

To the aqueous extract of each plant-part, $5 \mathrm{ml}$ of dil. Ammonia $\left(\mathrm{NH}_{3}\right)$ was added, followed by a few drops of conc. Sulphuric acid $\left(\mathrm{H}_{2} \mathrm{SO}_{4}\right)$. The appearance of yellow color indicated the presence of Flavonoids, which usually disappeared on standing.

\section{Test for Saponins}

\section{(Frothing Test)}

$0.5 \mathrm{ml}$ of each of the extract was added to $5 \mathrm{ml}$ of distilled water in a test-tube. Froth appeared in the solution on being shaken vigorously. This 'Frothing test' with the positive results indicated the presence of Saponins.

\section{Test for Tannins}

A few drops of $1 \%$ Ferric Chloride $\left(\mathrm{FeCl}_{3}\right)$ was added to the $10 \mathrm{ml}$ of aqueous filtrate of each of the extract. The appearance of brownish green or blue black coloration confirmed the presence of tannins.

\section{Test for Alkaloids}

(Dry extract precipitation test)

$4 \mathrm{ml}$ Methanol and $400 \mathrm{ml}$ of Glacial acetic acid, alongwith a few drops of Ammonia was added to the small quantity of dry plant-part extract. The precipitation indicated the presence of Alkaloids.

\section{Test for Terpenoids \\ (Salkowski test)}

$3 \mathrm{ml}$ of conc. Sulphuric acid $\left(\mathrm{H}_{2} \mathrm{SO}_{4}\right)$ was added to the solution of 0.5 gms extract mixed with $2 \mathrm{ml}$ of Chloroform $\left(\mathrm{CHCl}_{3}\right)$.

The presence of Terpenoids was detected by the appearance of reddish brown color at its interface.

A preliminary phytochemical screening for the presence of important phytochemical constituents in Achyranthes aspera was followed by a comparative analysis of the same. The extracts were prepared in different solvents, Methanol and Chloroform separately. The three main plant-parts considered for experimentation were, viz., Flower, Leaf and Root of Achyranthes aspera.

Table 1: Showing the comparative results of Phytochemical analysis of the Flower, Leaf and Root extracts of Achyranthes

\begin{tabular}{|l|c|c|c|c|c|c|}
\hline Extract of Plant $\longrightarrow$ & Fl. E. of Achyranthes aspera & \multicolumn{2}{|c|}{ Lf. E. of Achyranthes aspera } & \multicolumn{2}{c|}{ Rt. E. of Achyranthes aspera } \\
\hline Solvents & Methanol & Chloroform & Methanol & Chloroform & Methanol & Chloroform \\
\hline $\begin{array}{l}\text { Phytochemical } \\
\text { Constituents }\end{array}$ & & & & & & \\
\hline Cardiac glycosides & + & - & + & - & - & + \\
\hline Steroids & + & + & - & + & + & + \\
\hline Flavonoids & + & - & + & - & - & - \\
\hline Saponins & - & - & - & - & + & - \\
\hline Tannins & - & - & + & $\oplus$ & - & - \\
\hline Alkaloids & - & + & - & - & + & - \\
\hline Terpenoids & + & + & - & - & + & $\oplus$ \\
\hline
\end{tabular}

$+=$ Present ; ++ = Present in bulk ; $\oplus$ = Present in less amount ; - = Absent; Fl. E. = Flower Extract; Lf.E = Leaf Extract; Rt.E $=$ Root Extract

\section{Result and Discussion}

The phytochemical screening of flower, leaf and root extracts of Achyranthes aspera, prepared separately in two different solvents, Methanol and Chloroform, indicated the presence of many phytochemical compounds of pharmacological importance. Some of them, however were present in very less amounts or were almost absent. Methanolic extracts of three of the plant-parts, selected for the study, were detected to consist of sufficed amounts of phytoactive compounds as compared to the chloroformic extracts. Cardiac glycosides were significantly present in methanolic flower and leaf extracts of Achyranthes aspera, and sufficiently in chloroformic root extract. Rich sources of steroids were detected in both, methanolic and chloroformic extracts of flower and root. Flavonoids were prominently detected in flower and leaf extracts in methanol. The extracts of flower and root showed the presence of Terpenoids. Alkaloids were detected in chloroformic flower and methanolic root extracts of Achyranthes aspera. Saponins showed presence in root extract in methanol. Tannins were observed only in the extracts of leaf of Achyranthes aspera (Table 1).

The plants are the rich sources of phytochemicals. The phytochemical constituents contribute to the total antioxidant defense system of the human body, and hence in human health. They are the secondary metabolites that combine with nutrients, combat free radicals, and thus provide security against dreadful diseases and early ageing.

Phenolic acids and Flavonoids are the most important of all bioactive compounds in plants and good sources of natural antioxidants [13,14]. Flavonoids act as powerful antioxidants that protect the human body from the harm caused by free radicals and reactive oxygen species. They are also reported to show inhibitory activity against preoxidation of lecithin [15,16]. Flavonoids not only act as plant growth regulators, but also function in control of respiration, morphogenesis and sex-determination [17]. Such 


\section{International Journal of Science and Research (IJSR) \\ ISSN (Online): 2319-7064 \\ Index Copernicus Value (2013): 6.14 | Impact Factor (2014): 5.611}

phytochemical compounds also possess bioactivities, like anti-inflammatory, antidiabatic, anti-tumor, anti-cancer and anti-viral properties [18,19]. Phytochemical screening, as reported earlier, have revealed the presence of tannins in aqueous and ethanol extracts of Achyranthes aspera. This contributed to plants wound healing activity too [6]. Tannins also are known to cause anti-inflammatory effect due to decrease in vascular permeability [20].

Terpenoids are generally lipid-soluble and are located in the cytoplasm of the plant cells. They are associated with growth-regulating properties. Certain non-volatile terpenoids have been implicated as sex-hormones among the fungi. Many Alkaloids are modified terpenoids, and are toxic to human beings. Their remarkable physiological activities attribute to their wide use in medicine. Alkaloids also act as a form of nitrogen storage in plants. Steroids, Saponins and Cardiac glycosides are three important groups of Triterpenoids. Steroids were mainly considered as animal substances in the form of bile acids and sex-hormones. However, steroids are also reported from plant tissues, and are called 'Phytosterols'. Certain animal sterols, for instance, animal estrogen and estrone have been detected in some plant-tissues. Saponins of Achyranthes aspera are reported to have phosphorylase activity on the heart [21]. Cardiac glycosides occur in plant tissues as the complex mixtures. The toxic activity of both Saponins and Cardiac glycosides attribute to their pharmacological properties.

In the present study of phytochemical analysis of flower, leaf and root extracts of Achyranthes aspera, methanolic extracts were found to have the better stores of phytoactive compounds than the chloroformic extracts. The rich presence of Cardiac glycosides, Steroids, Flavonoids and Terpenoids in the flower of Achranthes aspera attribute to its antioxidant and medicinal properties. The roots also were observed as the good sources of bioactive compounds. Comparatively leaf of Achyranthes aspera showed less sources of phytochemical compounds.

\section{References}

[1] Anil Kumar Dhiman. (2006). Ayurvedic Drug Plants. Dhaya Publishing House, Delhi, 72-74.

[2] Chahlia N. (2009). Journal of Medicinal Plants Research, 3 (6) : 481-484.

[3] Charles Lekhya Priya, Gaurav Kumar, loganathan Karthik, Kokati Venkata Bhaskara Rao. (2010).Antioxidant activity of Achyranthes aspera Linn. Stem extracts. Pharmacologyonline, 2 : 228-237.

[4] Uniyal SK, Singh KN, Jamwal P, Lal B. (2006). Journal of Ethnobiology, 2 : 1-14.

[5] Pandey MM, Rastogi S, Rawat AK. (2008). The Internet Journal of Alternative Medicine, 6(1):1-10.

[6] Edwin S, Edwin Jarald E, Deb L, Jain A, Kinger H, Dutt KR, Amal Raj A.(2008). Wound healing and Antioxidant Activity of Achyranthes aspera. Pharmaceutical Biology, $46: 12,824-828$.

[7] Zafar R. (2009). Medicinal Plants of India. CBS Publishers \& Distributors. 1-15.

[8] Srivastav Sourabh, Singh Pradeep, Mishra Garima, Jha KK, Khosa RL. (2011). Achyranthes aspera- An important medicinal plant : A review. Journal of Natural Product of Plant Resource, 1(1) : 1-14.

[9] Khare CP. (2007). Indian Medicinal Plants. Springer, 1113.

[10] Nadkarni KM, (2009). Indian Materia Medica Bombay Popular Prakashan. Vol I : 21.

[11] Gupta RK. (2010). Medicinal and Aromatic Plants, CBS Publishers and Distributors, 190.

[12] Neeru V, Sharma SK. (2006). Post-coital antifertility activity of Achyranthes aspera Linn. root. Journal of Ethnopharmacol, 107 : 179-181.

[13] Kim JW, Han JY, Hong JT, Li R, Eun JS, Oh KW. (2011). Ethanol extract of the flower of Chrysanthemum morifolium, augments pentobarbital-induced sleep behavior : involvement of $\mathrm{Cl}$. Channel Activation Evidence-based Complementary and Alternative Medicine, Article ID, 109-164.

[14] Apak R, Guclu K, Demirata B, Ozyurek M, Esin CS, Bektasoglu B, Berker K, Ozyur D. (2007). Comparative evaluation of various total antioxidant capacity assays applied to phenolic compounds with the CUPRAC assay . Molecules, 12 : 1496-1547.

[15] Hanen F, Riadh K, Samia O, Sylvain G, Christian M, Chedly A. (2009). Interspecific variability of antioxidant activities and phenolic composition in Mesembryanthemum genus. Journal of Food Chemical Toxicology, 47 : 2308-2313.

[16] Ding M, Zhao JS, Bowman L, Lu YJ, Shi XL. (2010). Inhibition of AP-1 and MAPK signalling and activation of Nrf2/ARE pathway by quercitrin. International Journal of Oncology, 36 : 59-67.

[17] Harborne JB, Baxter H. (1999). The Handbook of Natural Flavonoids. Vol 1 \& 2. Chichester John Wiley \& Son,. $96: 612-632$.

[18] Palliwal S, Sundaram J, Mitragotri S. (2005). Induction of cancer-specific cytotoxicity towards human prostrate and skin cells using quercetin and ultra sound. British Journal of Cancer, 92 : 499-502.

[19] Ghasemzadeh A, Jaafar HZE. (2011). Anti-cancer and Anti-oxidant activities of Malaysian young ginger (Zingiber officinale Roscoe) varieties grown under different $\mathrm{CO}_{2}$ concentrations. Journal of Medicinal Plant Research, 5 : 3247-3255.

[20] Lopes CG, Sanches CCA, Nakamura VC, Filho DPB, Hernandes L, Mello PCJ. (2005). Influence of extracts of Stryphnodendron pollyphyllum Mart \& Stryphnodendron obovatum Benth on the cicatrisation of cutaneous wounds in rats. Journal of Ethnopharmacology, 99 : 265-272.

[21] Ram AK, Bhagwat AW, Gupta SS. (1971). Effect of the saponin of Achyranthes aspera on the phosphorylase activity of rat heart. Indian Journal of Physiology \& Pharmacology, 15 : 107-110. 